\title{
Mechanisms of accelerated atherosclerosis associated with IMIDs
}

\author{
Z Mallat \\ From 5th European Workshop on Immune-Mediated Inflammatory Diseases \\ Sitges-Barcelona, Spain. 1-3 December 2010
}

Atherosclerosis is a chronic inflammatory disease of the arterial wall responsible for most ischaemic cardiovascular diseases. Circulating levels of several cytokines are associated with disease burden, and CRP levels predict the risk of future cardiovascular events. Furthermore, the incidence of cardiovascular disease (CVD) is increased in patients with chronic systemic inflammatory diseases such as rheumatoid arthritis (RA) and systemic lupus erythematosus (SLE). Intriguingly however, classic circulating inflammatory biomarkers are not related to atherosclerosis progression in IMIDs, suggesting more subtle intricate links between atherosclerosis and IMIDs.

We have shown that subpopulations of regulatory $\mathrm{T}$ (Treg) cells potently inhibit atherosclerotic lesion development and inflammation. Our recent work indicates that defective clearance of apoptotic cells, a characteristic of SLE, impairs the regulatory immune response in atherosclerosis and accelerates lesion development and inflammation, suggesting an important interplay between innate and adaptive immunity in promoting lesion development and progression. On the other hand, we have recently reported that depletion of mature $B$ cells using CD20 monoclonal antibody induces a significant reduction of atherosclerosis in various mouse models of atherosclerosis. B cell depletion diminished $\mathrm{T}$ cell-derived IFN-gamma secretion and enhanced production of IL-17; neutralization of the latter abrogated CD20 antibodymediated atheroprotection. These results suggest that impairment of Treg cell function and activation of B cell

University of Cambridge, Cambridge, UK responses may be important pathophysiological links between IMIDs and atherosclerosis progression.

Published: 25 November 2010

doi:10.1186/1479-5876-8-S1-115

Cite this article as: Mallat: Mechanisms of accelerated atherosclerosis associated with IMIDs. Journal of Translational Medicine 2010 8(Suppl 1):115.

Submit your next manuscript to BioMed Central and take full advantage of:

- Convenient online submission

- Thorough peer review

- No space constraints or color figure charges

- Immediate publication on acceptance

- Inclusion in PubMed, CAS, Scopus and Google Scholar

- Research which is freely available for redistribution 